\title{
The Effect of Self-concept and Organizational Identity on Organizational Citizenship Behavior (A Case Study in Social Security Organization of Isfahan city)
}

\author{
Dr. Sayyed Mohsen Allameh \\ Assistant Professor, University of Isfahan, Isfahan, IRAN \\ E-mail: dr_allameh@yahoo.com \\ Saeed Alinajimi \\ M.A Graduate in Business management, University of Isfahan, Isfahan, IRAN \\ E-mail:saeed.najimi@yahoo.com \\ Ali kazemi \\ MS Graduate of University of najaf abad, Isfahan, IRAN \\ E-Mail: en_alikazemi975@yahoo.com
}

Accepted: December 04, 2011 Published: March 17, 2012

Doi:10.5296/ijhrs.v2i1.1119 URL: http://dx.doi.org/10.5296/ijhrs.v2i1.1119

\begin{abstract}
During the two recent decades, researchers of organizational behavior have paid special attention to extra-social behavior in organizations, and there has been specific focus on employees' affairs which are developed beyond formal job demands. Globalization era has created increased inter-individual mutual dependencies among organizations and groups. Thus, it has made more need for extra-social cooperation and interaction inside and outside the organizations. Therefore, organizational citizenship behavior plays a role in increasing the effectiveness and durability of the organization. The main purpose of this survey is to study the manner of impact of self-concept, and organizational identity on organizational citizenship behavior of employees of Social Security Corporation in Isfahan province and also to examine the existence of the balancing role of self-concept variable in the relationship between organizational identity and organizational citizenship behavior. This survey was conducted using descriptive-metrical method.

Obtained results of this survey reveal that organizational citizenship behavior is affected by organizational identity, and self-concept; and each variable of organizational identity has
\end{abstract}


positive correlation with organizational citizenship behavior. It means that by strengthening and improving the above variables it is possible to enhance organizational citizenship behavior. Also, results demonstrate that self-concept balances the relationship between organizational identity and organizational citizenship behavior.

Key words: organizational citizenship behavior, organizational identity, self-concept.

\section{1-Introduction}

Most researches about organizational citizenship behavior have focused on predicting factors that create such behaviors. In this regard, variables such as job satisfaction, organizational commitment, organizational justice, confidence, types of leadership, leader-follower relations and etc are mentioned as factors creating organizational citizenship behavior (podsakoff et al, 2000). We believe that self-concept and organizational identity in the working environment is one of the variables which has so far been neglected in spite of the fact that it has a high potential power in order to impact other organizational variables and probably organizational citizenship behavior. This relation is to be tested in this survey for the first time.

Nowadays identity has been changed into a unified framework of enlightenment discussions. It appears that organizational sociologists, psychologists, philosophers and theoreticians have something to say about it. On the other hand, not only has individual identity been studied, but social and organizational identities have been discussed, too. Recognition of organizational identities is as important as recognition of individual identities because international markets are becoming independent of limits of boundaries at present.

Each person has an image of himself/herself in his/her mind, in other words, total evaluation of the individual from his/her personality is called "self-concept". This evaluation is resulted from mental evaluations that we usually produce from our behavioral characteristics. As a result, self-concept could be positive or negative.

Concept of "self" as a dynamic organization was posited for the first time by Leckey. He believed that human's behavior is the demonstration and motivation, and its purpose is one's stability at instable conditions. Briefly we can say that self-concept is a cognitive framework by which we organize what we know about ourselves and process the information related to self based on it.

\section{2-Organizational Citizenship Behavior (OCB)}

Organizational citizenship behavior includes those behaviors related to performance that are not considered as functional performance. Such behaviors are described with concepts of extra-role behaviors, spontaneous behaviors and background performance. These behaviors were recognized for the first time by Organ and had a concept close to background performance. He defined organizational citizenship behavior as an individual and optional behavior that has not been recognized by formal reward system of the organization directly or implicitly, and is consistent with improvement of efficiency and effectiveness of the organization's performance (Torlak and Koc, 2007:582).

Generally, these behaviors include optional and voluntary behaviors. Despite the fact that 
there is no obligation to perform them by the organization and are role-related activities performed by the individual beyond job and duty expectations, some benefits are created for the organization in the shadow of performing them by employees. It means that they are not encouraged directly by reward but are led to increasing the organization's effectiveness. According to the above, definition we can mention four characteristics for organizational citizenship behavior:

i. Performed activities are not among expected job activities.

ii. Performed activities are self-motivated activities.

iii. These behaviors are defined neither formally nor explicitly in formal reward systems.

iv. These behaviors are towards the whole organization; however, they are not evaluated in effectiveness systems.

Researchers of organizational behavior have paid special attention to extrasocial behavior in organizations during the two recent decades, and there exists a special focus on employees' affairs that are developed beyond formal job demands (Desivilya, Sabag \& Ashton, 2006). Organ (1983) posited the organizational citizenship behavior (OCB) term in order to obtain such extrasocial behaviors. Globalization era has created increased mutual dependencies among individuals, groups and organizations. Therefore, it has created more need for extrasocial cooperation and interaction inside and outside the organizations. Consequently, a major role has been given to organizational citizenship behavior in increasing the effectiveness and durability of the organization (Katz, 1964; Smith et al, 1983; Lepine, Erez, \& Johnson, 2002; King, George \& Hebl, 2005).

2-1 Structure of Organizational Citizenship Behavior (OCB)

Researchers who have recently been working on organizational citizenship behavior (OCB) explain it with social psychological theories and behavior towards the society. This behavior takes various shapes. Indicators of this kind of behavior are directed in self-initiated forms and are in the benefit of special persons (usually strangers) without any expectation to obtain reward from the receiver of help (Organ, podsakoff \& Mackenzie, 2006).

There is no agreement about civil behaviors of the organization among researchers. Dimensions such as helping behaviors, organizational loyalty, obeying rules, and organizational obedience, innovation and individual initiation have been considered in researches. There are factors related to employees' behavior which help the organization through organizational civil behavior.

There are five aspects of urbanity based on Organ's classification: A) philantrophism or helping others, B) working conscience or involvement in the required behavior of the role and doing beyond the intended minimum level, C) sportsmanship or avoiding complaints about trivial and common issues, D) courtesy or providing notes, re-collectives and information for others, E) civil virtue or helping to a responsiveness routine for collective administration of the organization.

\section{Generalities of the organizational identity}

Issues related to identity have found an increasing application in current organizational researches (Albert and Veten, 1985; Ashford and Mayl, 1989; Karreman and Alyesson, 2001). Since the pioneer article of Albert and Veten was published defining organizational identity as 
what is discriminating and stable about a central organization, extensive range of researchers have appeared who tried to describe and analyze this ground theoretically (Thomas, 2007). According to Hatch \& Schultz (1997) the issue of identity in organizational studies is related to the concept of organizational identity.

Identity refers to the most fundamental perception that individuals have from themselves (Pratt \& Foreman, 2000; Schomaker \& Genc, 2003). As Karreman and Alyesson (2001) pointed out, questions such as "who am I" or "who are we" are considered as responses related to a discriminating or distinctive identity to some extent.

Creating a distinction between organizational identity and individual identity is important. Individual identity refers to individuals' perception about who they are (what they think about themselves) but organizational identity refers to what individuals think about their organization. Organizational identity is a metaphor to discuss and analyze what organizational members perceive, feel and think about their organization (Skalen, 2004). Albert and Veten (1985) have provided a basis for most researches of identity in an organizational ground. They have defined organizational identity as what organizational members believe to be discriminating and stable in a central organization. In their viewpoint, organizational identity is a cognitive framework to perceive reality, and is used as common presuppositions about the world that lead to collective measures (exactly like organizational culture). This concept is used as a dialogue about fantasy and reality (thus various identities could exist with regard to the organization) and also as collective demands about contents of the organization and as a place for individual assimilation. This could be observed in organizational subjects such as future outlook documents, commission announcements, and also in discussions and essentially in each kind of relation.

Boundaries of an organization are borders of its identity; what is perceived and what is not perceived, the person who is a member and the one who is not a member (because he doesn't satisfy common expectations), unique form and adjustment that separates the organization from its environment clearly, and what distinguishes the organization from other organizations (environment) (Thomas, 2007).

However, some researchers criticized Albert and Veten's conceptualization. The critique is related to the assumption that organizational identities are stable and unique. It has been claimed that identity can change permanently, just as an organization could have multiple organizational identities at one time (Gioia, Schultz \& Corley, 2000; Meyer, Bartunek \& Lacey, 2002).

Albert and Veten (1985) state organizational identities will be changed when organizations:

- Are formed.

- Lose what helps to create identity (like a manager or senior manager).

- Finish a work.

- Grow.

- Experience a change in the concept of "we" (like undertaking a job or merging) and

- Have experience of employees' reduction.

Strategic issues of the organization are inseparable parts of its identity and strategic change reveals change of identity (Givia and Thomas, 1996). Pratt and Foreman (2000) suggest that managers have power for re-structuralization of identities, omitting them if not appropriate, grouping them if necessary and integrating them if suitable. Similarly, management enjoys selecting, maintaining, nurturing or supporting those identities which have strategic value. In contrast to this line of argument, Collins and Purras (1996) argue that central ideology of an institution is a harmonized identity that is beyond the product or 
market's life cycle, technological improvements and temporary customs of management.

\section{Self-concept generalities}

Self-concept has various synonyms and definitions as a theoretical word. In research literature it has been defined as self-schema, self-representation, self-image, self-perception and self-esteem. When you are asked to describe yourself, probably you apply sentences in which words such as "I ", "mine", "me" and "myself" exist permanently. The image that James Carroll has depicted is that personal experiences, our interactions with others and cultural forces play a role in our description of ourselves. "Self" is a structure that includes a stable and organized structure from personal experiences of the individual. The important part of what we call "self" is knowledge. This knowledge is in fact all ideas, thoughts and information that we have about ourselves. Who we are, what characteristics we have, what our personal background is and what probably we are all build our self-concept (Brodense \& Horowitz, 2001). Individual self-concept shows aspects of self which are different from others and are stimulated in the direction of interest to oneself and individual purposes. Self is defined as a unique existence here (Whitesell, MichellT Kaufman \& Spicer, 2006). Collective self is a part of our self resulting from our membership in groups. This kind of self-concept reflects self-evaluation from special and important groups that the individual is a member of. Primary researches on groups illustrate that they have a strong impact on our self-concept that we are a member. Our behavior is often interpreted and affected by cases that the group members ask us (Brudence and Horvitz, 2001). In a quotation from Rikta (2005), Herbatch stated that individuals link their organizational membership (organizational commitment) with their self-concept. Individuals with collective self are committed to social relations and are defined with such relations in a bigger context (Vitsell, Micheal, Kaffman and Spicer, 2006). These two recent issues, i.e. individual self and collective self don't occupy an equal space in mind and don't have equal impacts on the individual's self-concept. Partial importance of each element in the individual's self-concept is determined by the culture in which he/she lives in macro size (Brudence and Horvitz, 2001).

\subsection{Main characteristics of self-concept}

Porky (1988) refers to three characteristics of organized, learnable and dynamic in describing self-concept characteristics. Self-concept is organized; it means that each individual has numerous perceptions about his/her identity and other perceptions are organized in harmonization with self-concept. Learnability means that no one is born with self-concept. It is created and formed gradually during early months of growth. Finally, dynamism of self-concept means that self-concept not only forms the individual's perceptions from himself/herself and his/her surrounding world but also it helps the individual obtain a permanent viewpoint from the life.

self-concept includes separate and inter-related dimensions. Although we talk about self-concept as a single creature, it is more correct to say that individuals have a number of specific self-concepts which act in different situations.

\section{Research Methodology}

Since the subject of this paper is the impact of organizational self-concept and identity on organizational citizenship behavior, identify how these relationships and the quality of their relationship in optimal design and develop of strategies related to human resources in organizations will have the valuable and applied role, we can to consider this study as an applied research.

Regarding to the current research is used methods such as library, specialized books and 


\section{MlMacrothink}

articles studies related to organizational behavior and human resources also field methods such as questionnaires, and the other hand, because its purpose is to determine the effect of organizational self-concept and identity On organizational citizenship behavior, it can was considered as a descriptive - survey study.

\subsection{Population}

Population is a complete set of possible measures or recorded data from a qualitative trait, in about complete collector of units that can be done inference's about it. Population of this study is the employee's of Social Security Organization of Isfahan city.

\subsection{Sampling method and sample size}

Sampling is a number of people, events and objects of a defined community as the community representative. Sampling has different types and the method used in this study is random sampling. Given that the study population numbers are 380 employees of social security organization in Isfahan and it is specified, with this cause following formula was used to determine the sample size.

Relationship 1:

$$
n \geq \frac{N \times Z \frac{\alpha}{2}^{2} \times S^{2}}{\varepsilon^{2}(N-1)+Z \frac{\alpha}{2}^{2} \times S^{2}}
$$

$$
\mathrm{n}=\text { sample size } \quad \mathrm{N}=\text { population size } \quad \mathrm{s}^{2} \text { : variance pre-estimation }
$$

$Z_{\frac{\alpha}{\alpha}}:$ the normal value for error level $\alpha \quad \varepsilon:$ rate of free error

$$
n \geq \frac{380 \times(1.96)^{2} \times(0.33)^{2}}{(0.05)^{2}(380-1)+(1.96)^{2} \times(0.33)^{2}}
$$

With the primary sampling among 30 employees, standard deviation was 0/332, with placement in the formula, with confidence coefficient 0/95; the number of final sample was 116. Since usually a percentage of questionnaires distributed are not returned, numbers 180 questionnaires distributed which 135 questionnaires were returned and finally 121 acceptable numbers questionnaires were based research.

\section{Research hypotheses:}

Hypothesis 1: Organizational Identity has effect on Organizational Citizenship Behavior in the Social Security Organization of Isfahan city.

Hypothesis 2: self-concept has effect on Organizational Citizenship Behavior in the Social Security Organization of Isfahan city.

Hypothesis 3: self concept moderates relationship between organizational identity and organizational citizenship behavior in the social security organization of Isfahan city.

\section{Testing the Research Hypotheses}

In this section according to data from research samples and by test a single independent sample, the hypotheses of one, two and three will be examined. 
Table 1: Correlations

\begin{tabular}{|c|c|c|c|c|c|c|c|c|c|}
\hline variable & $\begin{array}{l}\frac{0}{0} \\
\stackrel{0}{0} \\
0 \\
0\end{array}$ & 范 & $\begin{array}{l}\stackrel{8}{0} \\
\stackrel{0}{0} \\
\stackrel{0}{0} \\
\stackrel{0}{0}\end{array}$ & 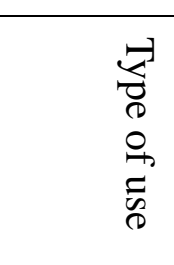 & 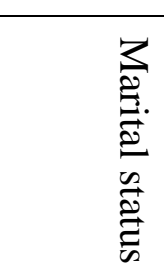 & 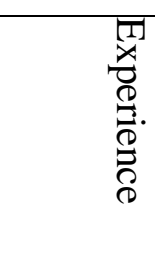 & §ి & $\stackrel{0}{0}$ & $\tilde{n}$ \\
\hline gender & 1 & & & & & & & & \\
\hline age & $0 / 278^{* *}$ & 1 & & & & & & & \\
\hline education & $-0 / 130$ & $-0 / 156$ & 1 & & & & & & \\
\hline Type of use & $0 / 199^{*}$ & $-0 / 532^{* *}$ & $-0 / 042$ & 1 & & & & & \\
\hline $\begin{array}{l}\text { Marital } \\
\text { status }\end{array}$ & $-0 / 290^{* *}$ & $-0 / 341^{* *}$ & $0 / 215^{*}$ & $0 / 286^{* *}$ & 1 & & & & \\
\hline experience & $0 / 308^{* *}$ & $* * 0 / 743$ & $-0 / 230^{*}$ & $-0 / 635^{* *}$ & $0 / 467^{* *}$ & 1 & & & \\
\hline ocb & $-0 / 100$ & $0 / 139$ & $0 / 049$ & $0 / 102$ & $0 / 102$ & $0 / 036$ & 1 & & \\
\hline OI & 0/019 & 0/017 & $-0 / 080$ & $-0 / 096$ & $0 / 173$ & $0 / 078$ & $0 / 370^{* *}$ & 1 & \\
\hline SC & $-0 / 136$ & $-0 / 083$ & $0 / 020$ & $0 / 019$ & $0 / 196$ & $-0 / 148$ & $0 / 365^{* *}$ & $0 / 150$ & 1 \\
\hline
\end{tabular}

$* \mathrm{p}<0 / 05 * * \mathrm{p}<0 / 01$

In table (1) internal correlation of research variables are shown

As table (1) is showed, organizational citizenship behavior is correlated with organizational identity $(r=0 / 370)$, which considering $p<0 / 01$, this relationship is significant. Also this table show that the relationship between organizational citizenship behavior and self concept are correlated $(365 / 0=r)$, which regarding to $p<0 / 01$, this correlation is significant.

The first hypothesis; organizational identity has effect on organizational citizenship behavior of employees in social security organization of Isfahan city. To investigating this relationship, the first part of this model will be analyzed.

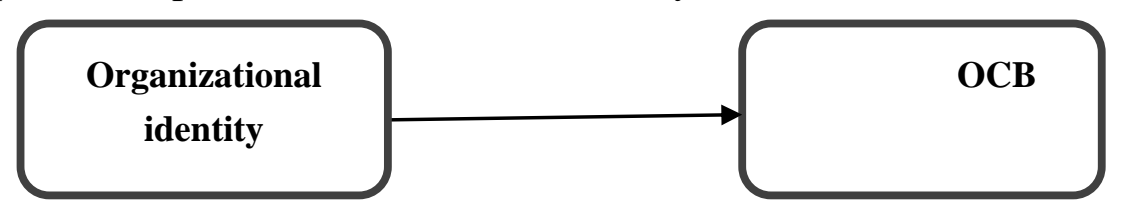

In the first part of the model, relationship of organizational identity as the dependent variable with organizational citizenship behavior was assessed, the results using SPSS software is as follows.

Table 2: Model Summary

\begin{tabular}{|l|l|l|l|}
\hline Model & $\begin{array}{l}\text { Std. Error of the } \\
\text { Estimate }\end{array}$ & $\mathrm{R}$ & R Square \\
\hline $\begin{array}{l}\text { Organizational } \\
\text { identity }\end{array}$ & $0 / 39536$ & $0 / 370$ & $0 / 137$ \\
\hline
\end{tabular}

summarizes the results of correlation between organizational identity and organizational citizenship behavior 
Table 3: ANOVA

\begin{tabular}{|l|l|l|l|l|l|}
\hline Model & $\begin{array}{l}\text { Sum of } \\
\text { Squares }\end{array}$ & Df & $\begin{array}{l}\text { Mean } \\
\text { Square }\end{array}$ & F & Sig \\
\hline Regression & $2 / 948$ & 1 & $2 / 948$ & $18 / 860$ & $0 / 000$ \\
\hline Residul & $18 / 601$ & 119 & $0 / 156$ & & \\
\hline Total & $21 / 548$ & 120 & & & \\
\hline
\end{tabular}

Results of ANOVA analysis of organizational identity and organizational citizenship behavior

Table 4: Coefficients

\begin{tabular}{|l|l|l|l|l|l|}
\hline Model & & $\begin{array}{l}\text { Un-standardized } \\
\text { Coefficients }\end{array}$ & $\begin{array}{l}\text { Standardized } \\
\text { Coefficients }\end{array}$ & $\mathrm{t}$ & sig \\
\cline { 2 - 6 } & Std.error & $\mathrm{B}$ & Beta & & \\
\hline constant & $0 / 167$ & $3 / 186$ & & $19 / 081$ & $0 / 000$ \\
\hline $\begin{array}{l}\text { Organizatio } \\
\text { nal identity }\end{array}$ & $0 / 048$ & $0 / 209$ & $0 / 370$ & $4 / 343$ & $0 / 000$ \\
\hline
\end{tabular}

summarizes the results of factor analysis of organizational identity and organizational citizenship behavior

According to Table (4) standardized impact factor for this hypothesis is $0 / 370$. Significant amount is zero and is lower than 0/05, which shows this hypothesis has confirmed. With confidence $0 / 95$ can be said organizational identity has the effect on organizational citizenship behavior of employee's social security organization of Isfahan city.

The second hypothesis; self concept has the effect on citizenship behavior of employee of social security organization of Isfahan city.

For investigating this relationship the second part of model will be analyzed.

In the second model, relationship of self-concept as a dependent variable with organizational citizenship behavior was assessed,

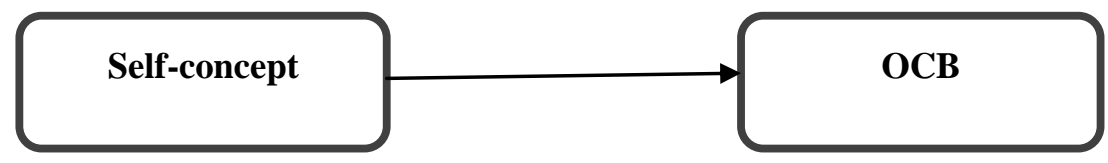

the results using SPSS software is as follows:

Table 5: Model Summary

\begin{tabular}{|l|l|l|l|}
\hline Model & $\mathrm{R}$ & R Square & $\begin{array}{l}\text { Std. Error of the } \\
\text { Estimate }\end{array}$ \\
\hline Self-concept & $0 / 365$ & $0 / 134$ & $0 / 396$ \\
\hline
\end{tabular}

summarizes the results of analyzing the correlation between self-concept and organizational citizenship behavior 
Table 6: ANOVA

\begin{tabular}{|l|l|l|l|l|l|}
\hline Model & $\begin{array}{l}\text { Sum of } \\
\text { Squares }\end{array}$ & Df & $\begin{array}{l}\text { Mean } \\
\text { Square }\end{array}$ & F & Sig \\
\hline Regression & $2 / 877$ & 1 & $2 / 877$ & $18 / 340$ & $0 / 000$ \\
\hline Residul & $18 / 671$ & 119 & $0 / 157$ & & \\
\hline Total & $21 / 548$ & 120 & & & \\
\hline
\end{tabular}

Results of ANOVA analysis of self-concept and organizational citizenship behavior

Table 7: coefficients

\begin{tabular}{|l|l|l|l|l|l|}
\hline \multirow{2}{*}{ Model } & \multicolumn{2}{|l|}{$\begin{array}{l}\text { Un-standardized } \\
\text { Coefficients }\end{array}$} & $\begin{array}{l}\text { Standardized } \\
\text { Coefficients }\end{array}$ & $\mathrm{t}$ & \multirow{2}{*}{ Sig } \\
\cline { 2 - 4 } & $\mathrm{B}$ & Std.error & Beta & \\
\hline constant & $2 / 918$ & $0 / 231$ & & $12 / 643$ & $0 / 000$ \\
\hline $\begin{array}{l}\text { Self-concep } \\
\mathrm{t}\end{array}$ & $0 / 277$ & $0 / 065$ & $0 / 365$ & $4 / 282$ & $0 / 000$ \\
\hline
\end{tabular}

summarizes the results of factor analysis of self-concept and organizational citizenship behavior

According to Table (7), standardized impact factor for this hypothesis is $0 / 365$. Significant amount is zero and is lower than 0/05, which shows this hypothesis has confirmed. With 95 / 0 on the self can be said employee organizational citizenship behavior Social Security Organization of Isfahan has effect.

The third hypothesis; self concept moderates relationship between organizational identity and organizational citizenship behavior in the social security organization of Isfahan city.

To examine whether the self concept is a moderator variable in relationship between organizational identity and organizational citizenship behavior or not, must be proved that it will affect the relationship between of independent variables (organizational identity) and dependent (organizational citizenship behavior).

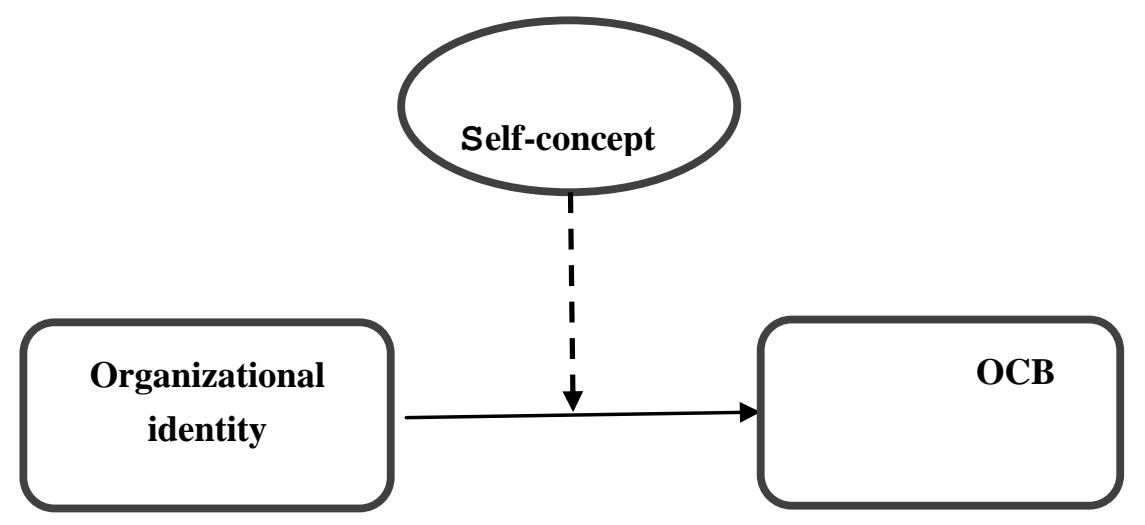

For this purpose, stepwise regression is used. Firstly the relationship between self concept and organizational citizenship behavior is investigated and the it's regression coefficient is calculated, then by entering the self concept variable to this relationship, rate of correlation coefficient and its effect factor is calculated. In third stage, The product of self concept and organizational identity variables enter into relationship and correlation 
coefficient and rate of effect are calculated, then trough this way be realized to moderating role of self concept variable. That considering to the correlation and effect coefficient calculated and differences between them and also the significant amount of its will intoned to moderating role of self concept variable.

Table 8: Model Summary

\begin{tabular}{|l|l|l|l|l|l|l|}
\hline Model & R & $\begin{array}{l}\text { R } \\
\text { Square }\end{array}$ & $\begin{array}{l}\text { Std. Error of } \\
\text { the Estimate }\end{array}$ & $\begin{array}{l}\text { R square } \\
\text { change }\end{array}$ & $\begin{array}{l}\text { F } \\
\text { change }\end{array}$ & $\begin{array}{l}\text { Sig. F } \\
\text { change }\end{array}$ \\
\hline )OI( & $0 / 370$ & $0 / 137$ & $0 / 3953$ & $0 / 137$ & & $0 / 000$ \\
\hline )SC ( & $0 / 410$ & $0 / 168$ & $0 / 3898$ & $0 / 098$ & & $0 / 000$ \\
\hline OI*SC & $0 / 511$ & $0 / 261$ & $0 / 369$ & $0 / 026$ & $4 / 070$ & $0 / 04$ \\
\hline
\end{tabular}

summarizes the results of moderating role of self concept variable

Table 9: Coefficients

\begin{tabular}{|c|c|c|c|c|c|c|}
\hline \multicolumn{2}{|c|}{ Model } & \multicolumn{2}{|c|}{$\begin{array}{l}\text { Un-standardized } \\
\text { Coefficients }\end{array}$} & \multirow{2}{*}{$\begin{array}{l}\text { Standard } \\
\text { ized } \\
\text { Coeffici } \\
\text { ents } \\
\text { Beta }\end{array}$} & \multirow[t]{2}{*}{$\mathrm{t}$} & \multirow[t]{2}{*}{ sig } \\
\hline & & B & Std.error & & & \\
\hline & (constant) & $3 / 186$ & $0 / 167$ & & $19 / 081$ & $0 / 000$ \\
\hline 1 & $\mathrm{OI}$ & $0 / 209$ & $0 / 048$ & $0 / 370$ & $4 / 343$ & $0 / 000$ \\
\hline \multirow{3}{*}{2} & $($ constant $)$ & $2 / 431$ & $0 / 250$ & & $9 / 714$ & $0 / 000$ \\
\hline & $\mathrm{OI}$ & $0 / 182$ & $0 / 046$ & $0 / 322$ & $3 / 956$ & $0 / 000$ \\
\hline & $\mathrm{SC}$ & $0 / 240$ & $0 / 062$ & $0 / 317$ & $3 / 892$ & $0 / 000$ \\
\hline \multirow{4}{*}{3} & (constant) & $1 / 873$ & $0 / 371$ & & & $0 / 000$ \\
\hline & $\mathrm{OI}$ & $0 / 419$ & $0 / 126$ & $0 / 742$ & $3 / 236$ & $0 / 001$ \\
\hline & $\mathrm{SC}$ & $0 / 355$ & $0 / 083$ & $0 / 468$ & $4 / 262$ & $0 / 000$ \\
\hline & $\mathrm{Oi} * \mathrm{Sc}$ & $-0 / 056$ & $0 / 028$ & $-0 / 494$ & $-2 / 018$ & $0 / 046$ \\
\hline
\end{tabular}

summarizes the results of factor analysis

According to the results in Table (9), the regression coefficient is $-0 / 494$ and significant rate is $0 / 04$, that considering less than $0 / 05$ is significant. This show that Fourth hypothesis is confirmed. Thus with $95 \%$ confidence can be said the self concept will moderate relationship between organizational identity and self organizational citizenship behavior among Social Security employees of Isfahan city.

\section{Conclusion and recommendations}

Organizational citizenship behavior has a determinant role in the organizational process and in changing the traditional environment into a dynamic and efficient environment as one of the new concepts of organizational behavior management which puts emphasis upon employees and managers' extra-role behaviors.

Organizations are social systems whose members interact with each other and external 
situations (like customers and producers). While complicated organizational outputs are dependent upon continuous participatory activities among individuals, organizational citizenship behavior has been regarded as one of the most favorable studies in organizational performance during the recent decade. This phenomenon has been studied in more than 270 studies and its importance in management studies in all sectors and cultures has been stressed. Such self-stimulated behaviors play a significant role in effectiveness, efficiency and creating a positive atmosphere in the working environment by individuals theoretically. So, managers and employees must be encouraged to increase their arbitrary activities.

As it was pointed out, organizational citizenship behavior has a correlation with organizational identity $(\mathrm{R}=0.370)$ and this relation is significant given it has $\mathrm{P}<0.01$. This direct and positive relation states that it is possible to enhance organizational citizenship behavior in individuals by reinforcing organizational identity. Also, it has been pointed that the coefficient of standardized effect is 0.370 for this hypothesis. Amount of significance is equal to zero, that is lower than 0.05 and shows confirmation of this hypothesis. With 0.95 confidence, we can say that organizational identity affects organizational citizenship behavior of social security employees in Isfahan province.

Quality and manner of effectiveness depends on the level of organizational identity among employees of the organization. In other words, a feeling of singleness is created among individuals and the organization by increasing the level of organizational identity that leads to emphasis on the main and inseparable role of employees for the organization. This has resulted in recognizing individuals' help to the organization and in increasing employees' common values. High organizational identity in the organization causes individuals to embark upon undertaking duties that they are not asked to perform but enhance organizational image and performance. Also, they consider benefits towards individuals inside the organization like philantrophism and inter-individual help to colleagues who have heavier working which has resulted in enhancing organizational citizenship behavior in the organization. Therefore, we conclude that we can embark on increasing organizational citizenship behavior through enhancing its components- like philantrophism or helping others, working conscience or involvement in the intended behavior of the role and performing beyond the required level, sportsmanship or avoiding complaints about insignificant and common issues, courtesy or providing notes, recollectives or information for others and also civil virtue or helping a responsiveness routine for collective administration of the organization through enhancing and improving this relation and increasing organizational identity and creating a singleness feeling among employees and the organization.

As it has been pointed out, the relation between organizational citizenship behavior and self-concept has a correlation $(\mathrm{R}=0.365)$ which is significant given that it has $\mathrm{P}<0.01$. Also, coefficient of standardized effect is equal to 0.365 for this hypothesis. Amount of significance is equal to zero that is lower than 0.05 and shows confirmation of the hypothesis. With 0.95 confidence, we can say that organizational identity affects organizational citizenship behavior of employees of Social Security Corporation in Isfahan province. Hence, we can conclude that it is possible to increase organizational citizenship behavior through improving and enhancing this relation and reinforcing positive self-concept of employees by paying attention to the positive and significant effect of self-concept on organizational citizenship behavior among social security employees in Isfahan province.

In addition, results of analysis demonstrate that when self-concept variable is inserted, correlation coefficient is higher than when the independent variable (organizational identity) and the dependent variable affect each other alone. Self-concept variable acts as a regulating variable, and we can reinforce this relation in order to improve the relation between organizational identity and organizational citizenship behavior by improving self-concept. 
Paying attention to human characteristics and factors has an undeniable effect on organizational citizenship behavior. So, managers' attempt for creating and reinforcing strong organizational identity and organizational citizenship behavior is like focusing and investing in organizational citizenship behavior. Managers' attention and focus on creating and reinforcing organizational identity and considering central values of the organization encourages employees towards each element of organizational citizenship behavior totally. As it has been mentioned, organizational identity shows the highest relation with organizational citizenship behavior by correlation degree of 0.370 Then, there is self-concept with correlation degree of 0.365 . Thus, managers can determine quality and prioritization of the organization's focus on variables based on the amount of effect of each variable on their codified programs and policies.

Organizational citizenship behavior could be a useful and efficient tool for converting the work force into a valuable social capital which helps the organization to gain prominent competitive benefits and privileges from two aspects, i.e. it will be useful for both for the organization and employees.

\section{References}

Akan, O. H , Allen,R. S. ,\&White,C. S. (2009). Equity sensitivity and organizational citizenship behavior in a team environment. Small Group Research, 40, 1, 94-112.

Albert, S., \& Whetten, D. (1985). Organizational identity. In : L.L. Cummings and B.m Staw (Eds.). Research in organizational behavior, 263

Borman , W. C., and Motowidlo, S. J. (1997). Task performance and contextual performance: The meaning for personnel selection research. Human Performance, 10, 99-109.

Bosma, H.a., \& Kunnen, E.S.(2001). Determinants and mechanisms in ego identity development. A review and synthesis Developmental Review, 21, 39-66.

Broadens, S. K \& Horowitz, A. I. (2001). Social Psychology: The social self ( $2^{\text {nd }}$ ed.), UK: Lawrence Erlbaum Associates.

Bryan, D. D. (2007). The relationship between organizational climate, personality factors and organizational citizenship behaviors in a university extension. available in proQuest Dissertation \& theses website.

Campbell,J. \& Wilkins,S. (2007). Faculty identity: an exploratory study using social identity theory, The University of Kentucky.

Campbell, J.P.(1990). Modeling the performance prediction problem in industrial and organizational Psychology. In: M.D Dunnette \& L. M .Hough (Eds), Handbook of industrial and organization psychology, 1, 687-732.

Cohen, a., \& Vigoda, E. (2000). Do good citizen make good organizational citizens? An empirical examination of the relationship between general citizenship and organizational citizenship behavior in Israel. Administration and Socially, 32, 5, 596-625.

Erturk, A. (2007). Increasing organization citizenship behaviors of Turkish Academicians, Journal of Managerial Psychology, 22, 3, 257-270.

Hui, C., Law, K.S., and Chen, Z.X. (1999). A structural equation model of the effects of negative affectivity, leader-member exchange, and perceived job mobility on in-role and extra-role performance: A Chinese case. Organizational Behavior and Human 
Decision Processes, 77, 3-21.

JoHatch ,M. and Schultz ,M.(2004). Organizational Identity. Publication of Oxford University.

Katz, D., and Kahn, R. L,(1966). The social Psychology of Organization. New York: John Wiley.

Katz, D.(1964). The motivational basis of organizational behavior. Behavioral science, 9, 2, 131-146.

King, E.B., George, J.M., \& Hebl, M.R. (2005). Linking personality to helping behaviors at work: an interactional perspective. Journal of Personality, 73, 586-607.

Markoczy ,L. and xin, K. (2004). The virtues of omission in organizational citizenship behavior. University of California

Mayfield ,C. (2008). The Effects Of Self-Concept and Organizational Identification on Organizational Citizenship Behavior, The Degree of Doctor, Albany

Organ, D. W. (1988). Organizational Citizenship Behavior: The Good Soldier Syndrome. Lexington Books.

Organ,W . D ,Podsakoff,M. P \& Maackenzie. B. S. (2006). Organizational Citizenship Behavior: Its nature, antecedents, and consequences. UK: SAGE Publication Inc.

Podsakoff, P.M., MacKenzie, S.B., Moorman, R.H. and Fetter, R. (1990). Transformational leader behaviors and their effects on followers' trust in leader, satisfaction, and organizational citizenship behavior, Leadership Quarterly, 1, 107-42.

Podsakoff, P. M., MacKenzie, S. B., Paine, J. B. and Bachrach, D. G. (2000). Organizational citizenship behaviors: A critical review of the theoretical and empirical literature and suggestions for future research. Journal of Management, 26, 3, 513-563

Podsakoff, P. M. , Ahearne, M, \& Mackenzie,S. (1997). Organizational citizenship behavior and the quantity and quality of work group performance. Journal of Applied Psychology. 82, 2, 262-270.

Podsakoff, P. M., MacKenzie, S. B., Paine, J. B. and Bachrach, D. G. (2000). Organizational citizenship behaviors: A critical review of the theoretical and empirical literature and suggestions for future research. Journal of Management, 26, 3, 513-563.

Purkey, W. W. (1988). An overview of self concept theory for counselors, ERIC Clearinghouse on counseling and personnel services Ann Arbor MI.

Torlak,O. \&Koc,U. (2007). Materialistic attitude as and antecedent of organization citizenship behavior. Management Research News, 30, 8, 581-596. 